\title{
Impact of Advancement in Technology, False Conclusion of Real Estate Bubble, Record Low Mortgage Delinquency, Irresponsible Media, U.S. Economic Policy Disaster: Evidence Supporting Eddison Walters Risk Expectation Theory of The Global Financial Crisis of 2007 and 2008
}

\author{
Dr. Eddison T. Walters ${ }^{1}$ \\ ${ }^{1}$ Walters Global Business Resources LLC, 170 NE $2{ }^{\text {nd }}$ Street, \#4065, Boca Raton, FL 33429, USA \\ Correspondence: Dr. Eddison T. Walters, Walters Global Business Resources LLC, 170 NE 2nd Street, \#4065, \\ Boca Raton, FL 33429, USA.
}

Received: May 19, 2020

doi:10.5539/ibr.v13n7p224
Accepted: June 16, 2020

Online Published: June 23, 2020

URL: https://doi.org/10.5539/ibr.v13n7p224

\begin{abstract}
Data analysis in recent studies by the current researcher presented evidence suggesting the existence of a real estate bubble preceding the Global Financial Crisis of 2007 and 2008 was a false conclusion. Data analysis from Walters (2019) resulted in 194.041 Mean Dependent Variable, 0.989 Adjusted R-square, 5.908 Square Error of Regression, and 488.726 Sum-of-Square Residual, from nonlinear regression analysis with the independent variable of "advancement in technology", which proved to be the most significant factor causing the dependent variable of "home purchase price" to increase preceding the Global Financial Crisis of 2007 and 2008. Based on the findings of data analysis in Walters (2019), the researcher concluded the data confirmed the assertion agreed upon by Alan Greenspan and Ben Bernanke, it was impossible to have a real estate bubble, while citing the Efficient Market Hypothesis in 2005. Subsequent to 2005, alternative attempts to explain the existence of a real estate bubble were made by both former Chairmen of the Federal Reserve Board. Subprime lending and low interest rates were ruled out as the cause of the Global Financial Crisis of 2007 and 2008 in Walters (2019). As a result of the findings from Walters (2019), further investigation to gain an understanding of the impact of how the rapid adaption of advancement in technology influence on the rapid increase in home purchase price preceding the Global Financial Crisis of 2007 and 2008 is required. The purpose of this study is to gain an understanding of the role the rapid adaption of advancement in technology played in the mortgage industry and real estate industry in the United States, and the influence on to the rapid increase in home purchase prices preceding the Global Financial Crisis of 2007 and 2008 as a result of the changes. Insight into the rapid transformation of the mortgage industry and the real estate industry in the United States, and the role the transformation played in the crisis is a critical factor to understanding the impact of advancement in technology on the real estate market in the United States preceding the Global Financial Crisis of 2007 and 2008. Failure to consider the impact of rapid adaption of advancement in technology on the mortgage industry and real estate industry, and the transformation of the real estate market preceding the Global Financial Crisis 2007 and 2008, was a significant error which led to the false conclusion of the existence of a real estate bubble. An understanding of how the rapid transformation of the real estate market as a result of advancement in technology in the United States preceding the Global Financial Crisis of 2007 and 2008, will provide the critical knowledge to evaluate mistakes leading to the false conclusion of a real estate bubble preceding the crisis. The information gained from the current study will help avoid a future financial crisis of the same magnitude.
\end{abstract}

Keywords: global financial crisis of 2007 and 2008,mortgage underwriting, automated underwriting (AU), customized application scoring models, conventional mortgage, government-backed mortgages, advancement in technology, mortgage delinquency, Federal Housing Finance Agency (FHFA), Fannie Mae, real estate bubble, financial bubble, Eddison Walters Risk expectation theory of the Global Financial Crisis of 2007 and 2008

\section{Introduction}

The purpose of the current research, is to gain an understanding of the role the rapid adaption of advancement in 
technology played in the mortgage industry and the real estate industry in the United States, which led to the rapid increase in home purchase prices preceding the Global Financial Crisis of 2007 and 2008. Insight into the rapid transformation of the mortgage industry and the real estate industry in the United States is a critical factor in understanding the impact of the rapid adaption of advancement in technology on the real estate market in the United States preceding the Global Financial Crisis of 2007 and 2008. Failure to consider the impact of the rapid adaptation advancement in technology on the mortgage industry and the real estate industry preceding the Global Financial Crisis was a significant error, which led to the false conclusion of the existence of a real estate bubble preceding the Global Financial Crisis of 2007 and 2008. Gaining understanding of the rapid transformation of both the mortgage industry and the real estate industry in the United States preceding the Global Financial Crisis of 2007 and 2008, will provide the critical knowledge for evaluating the mistakes leading to the false conclusion of a real estate bubble preceding the crisis. Lessons learned by gaining an understanding from the mistakes made, will help avoid another future financial crisis of the same magnitude.

\section{Background of Study}

Data analysis resulted in findings of the recent study suggesting the existence of a real estate bubble preceding the Global Financial Crisis of 2007 and 2008 was a false conclusion. Data analysis from additional research that resulted in 194.041 Mean Dependent Variable, 0.989 Adjusted R-square, 5.908 Square Error of Regression, and 488.726 Sum-of-Square Residual, from nonlinear regression analysis with the independent variable "advancement in technology", which was proven to be the most significant factor causing the dependent variable "home purchase price" to increase preceding the Global Financial Crisis of 2007 and 2008. The researcher called for further investigation into the impact of rapid adaption of advancement in technology on mortgage lending and real estate marketing in the United States preceding the Global Financial Crisis of 2007 and 2008. The investigation of the impact of rapid adaption of advancement in technology on mortgage lending in the United States preceding the Global Financial Crisis of 2007 and 2008 will significantly contribute the body of literature. The knowledge gained from the current research is critical to understand of the circumstance that led to false conclusion of a real estate bubble preceding the Global Financial Crisis of 2007 and 2008. The knowledge gained is critical to avoiding the same mistake, leading to another financial crisis of the same magnitude in the future.

\section{Statement of the Problem}

The failure to consider the role of rapid adaptation of advancement in technology on rapid increase in home purchase price in the United States was a critical error that led to the false conclusion of the existence a real estate bubble in the United States preceding the 2008 real estate crash, which was blamed as the cause of the Global Financial Crisis of 2007 and 2008. Questions raised by research resulted in 194.041 Mean Dependent Variable, 0.989 Adjusted R-square, 5.908 Square Error of Regression, and 488.726 Sum-of-Square Residual, from nonlinear regression analysis, with the independent variable "advancement in technology" was suggested to be the most significant factor causing the dependent variable "home purchase price" to increase preceding the Global Financial Crisis of 2007 and 2008. The knowledge gained is critical to avoiding the same mistake, leading to another financial crisis of the same magnitude in the future.

\section{Purpose of Study}

The current research is focused on gaining an understanding of the impact of rapid adaptation of advancement in technology on mortgage industry in the United States preceding the Global Financial Crisis of 2007 and 2008. The false conclusion of the existence of a real estate bubble, resulting from the failure to consider the impact of rapid adaptation of technology on the on the rapid increase in home purchase price preceding the Global Financial Crisis of 2007 and 2008 require additional investigation. Eddison Walters Risk Expectation Theory of The Global Financial Crisis of 2007 and 2008 was developed to explain the impact of technology on the rapid increase in home purchase price and the idea that the false claim of the existence of a real estate bubble preceding Global Financial Crisis of 2007 and 2008, which was blamed as the cause of the crisis. Gaining insight into the impact of rapid adaptation of advancement in technology on the mortgage industry and the real estate industry in the United States will provide additional insight, leading to a greater understanding of the cause Global Financial Crisis of 2007 and 2008.

\section{Research Question}

Does the data provide evidence supporting the idea, the failure to consider the impact of rapid adaption of advancement in technology on the mortgage industry and the real estate industry in the United States preceding the Global Financial Crisis of 2007 and 2008 the most critical mistake that lead to the false conclusion of a real estate bubble United States housing market that based on the Eddison Walters Risk Expectation Theory of the 
Global Financial Crisis of 2007 and 2008?

Ho: The evidence suggested, the failure to consider the impact of rapid adaptation of advancement in technology on mortgage lending and the real estate industry in the United States was not the most critical factor that led to the false conclusion of the existence of a real estate bubble in the United States preceding the Global Financial Crisis of 2007 and 2008.

Ha: The evidence suggested, the failure to consider the impact of rapid adaptation of advancement in technology on mortgage lending and the real estate industry in the United States was the most critical factor that led to the false conclusion of the existence of a real estate bubble in the United States preceding the Global Financial Crisis of 2007 and 2008.

\section{Nature of Study and Scope}

The current research was a quantitative investigation, using secondary data from the Federal Housing Finance Agency Database and the World Bank Database. The focus of the research was to gain an understanding of the impact of advancement in technology on mortgage lending and the real estate industry in the United States preceding the Global Financial Crisis of 2007 and 2008.

\section{Limitations}

The current research considered the impact of changes from the rapid adaption of advancement in technology in the mortgage industry and real estate industry in United States preceding the Global Financial Crisis of 2007 and 2008. The study was limited to the availability of data from secondary databases.

\section{Literature Review}

Walters (2018) presented evidence leading to the conclusion, the idea of an abundance of capital flowing into developed countries preceding Global Financial Crisis of 2007 and 2008 was a false conclusion. The researcher analyzed inward flowing foreign direct investment (FDI) data from 34 developed countries and 36 developing with the result of data analysis showing no significant statically difference between the inward flow of FDI between the period preceding and subsequent the Global Financial Crisis of 2007 and 2008 (Walters, 2018). Based on the results of the analysis in Walters (2018) and the lack of evidence supporting the existence of a financial bubble, serious questions were raised of the existence of a real estate bubble, which was blamed for causing the Global Financial Crisis of 2007 and 2008.

Eddison Walters Risk Expectation Theory of the Global Financial Crisis of 2007 and 2008 was developed to provide an alternative explanation for the cause of the Global Financial Crisis of 2007 and 2008 in Walters (2018). The theory presented the idea; High-risk expectation stemming false information by the media caused the real estate crash in the United States that led the Global Financial Crisis of 2007 and 2008. The lack of understanding of the impact of advancement in technology on the increase in home purchase price led to the false conclusion of a real estate bubble. Predictions of a real estate crash as a result of a real estate bubble that did no exist, was the subject of constant coverage by the irresponsible media preceding the financial crisis (Walters, 2018). The theory concluded, constant media coverage increased risk expectation of mortgage lenders to levels that caused fairs from a real estate crash to increase so severally; investors in mortgage-backed securities withdrew investments due to the increased risk expectation. The result was, the real estate lending stopped, due to the lack of mortgage capital. The lack of capital caused the United States subprime mortgage industry to crash. The significant reduction in mortgage lending led to a real estate crash in the United States. The real estate market crashed led to the subsequent worldwide economic crisis that followed (Walters, 2018).

Walters and Djokic (2019) presented evidence leading to the conclusion, the existence of a real estate bubble in the United States preceding the Global Financial Crisis of 2007 and 2008 was a false conclusion, helping build the case for Eddison Walters Risk Expectation Theory of the Global Financial Crisis of 2007 and 2008. The researcher analyzed data including growth in home purchase price, loan-price-ratio and interest rates. Findings of the research concluded, the idea of homeowners purchasing home with little or no down payment, as the cause of a real estate bubble preceding the Global Financial Crisis 2007 and 2008 was false. Down payment on homes preceding the crisis was significantly high than the period subsequent to the crisis following an increasing trend (Walters \& Djokic, 2019). The analysis of interest rates concluded, interest rates were much lower for the period subsequent to the crisis. The researcher to concluded, low interest rates for too long a period preceding the crisis was highly unlikely to have been the cause of a real estate bubble preceding the crisis (Walters \& Djokic, 2019). The analysis of the growth rate in home purchase price preceding the Global Financial Crisis of 2007 and 2008 concluded, no statistically significant difference in the growth of home purchase price, which continued to grow at an almost identical rate subsequent the Global Financial Crisis of 2007 and 2008. As a result of the analysis in 
the study the researcher concluded, the idea of a real estate bubble in the United States preceding the Global Financial Crisis of 2007 and 2008 was a false conclusion (Walters \& Djokic, 2019).

Walters (2019) presented evidence leading to the conclusion, the increase in home purchase price in the Unites States preceding the Global Financial Crisis of 2007 and 2008 was as a result of the rapid adaptation of advancement in technology, which confirmed the Eddison Walters Risk Expectation Theory of the Global Financial Crisis of 2007 and 2008. Data analysis from the study by the current researcher resulted in 194.041 Mean Dependent Variable, 0.989 Adjusted R-square, 5.908 Square Error of Regression, and 488.726 Sum-of-Square residual from nonlinear regression analysis with the independent variable of "advancement in technology", which proved to be the most significant factor causing the dependent variable of "home purchase price" to increase preceding the Global Financial Crisis of 2007 and 2008 (Walters, 2019).

Based on the findings in Walters (2019), the researcher concluded, the data confirmed the assertion by Alan Greenspanthat noted, no real estate bubble existed in Belke and Wiedmann (2005)., while citing the Efficient Market Hypothesis. Both Alan Greenspan and Ben Bernanke were also cited in Starr (2012) for supporting the idea it was imposable to have a real estate bubble. Double-digit increase in home purchase price was described in Roach (2005) as a challenge, which was the most significant challenge for Alen Greenspan. Subsequent to 2005, alternative attempts to explain the existence of a real estate bubble were made by former Chairman of the Federal Reserve Board Alen Greenspan (Greenspan et. al 2010; Khayoyan, 2012; Starr, 2012). Both subprime lending and low interest rates were ruled out as the cause of the Global Financial Crisis of 2007 and 2008 (Walters, 2019). The conclusion by the Walters (2019), advancement in technology was responsible for the increase in home purchase price preceding the Global Financial Crisis of 2007 and 2008.

The findings of Glynn, Huge and Hoffman (2008) revealed a relationship between the type and frequency of media coverage of the housing market and the perceptions developed by the public. The article cited Barsky (2005) which noted, the dismissal of fears of a real estate bubble in a July 2005 column in the Wall Street Journal that concluded fears were unfounded scares, exaggerations and lies from economists and journalists (Glynn et. Al, 2008). The Glynn et. Al (2008) noted, the housing bubble, the impact of the bubble bursting on the United States economy, and responsibility for causing inflation of home prices became the dominant economic topic in the media between 2005 and 2006. Subprime mortgage lending was eventually labeled as the major cause of inflated home prices as a slowdown in the housing market started developing in late 2006 (Glynn et. Al, 2008). Glynn et Al (2008) noted, between 1996 and 2007 media coverage of the housing market in the United States changed significantly as the gloom-and-doom narrative developed in the United States real estate market. Dating back several years before the literature Belke and Wiedmann (2005) was published, the research article also noted, significant coverage of economists reporting the existence of a real estate bubble in the United States and other developed countries throughout the media. By late 2006 the media had abandoned reporting on economic conditions and statistics in favor of the sensationalized coverage of the housing market had painted subprime mortgage brokers and people who bought homes they could not afford, with risky loans as the villains in the story.

The literatures describe media coverage of economist with clams of the existence of a real estate bubble in California real estate market. Starr (2012) noted, $40.5 \%$ of economists declared home prices in California had increased too fast and predicted the real estate market would experience significant decline by 2002. Analysis of media coverage in the real estate market by 24 California newspapers resulted findings of 379 newspaper articles, in which economist views of the existence of a real estate bubble were noted 688 times, with 1,153 quotes directly on the topic of a real estate bubble between 2002 and 2007 (Starr, 2012). Starr (2012) noted, over 80\% of economists were predicting a real estate crash in the United States by 2004, due to the rapid increase in home prices.

Straka (2000) discussed the transformation of the mortgage industry as a result of advancement in technology in the 1990's. The researcher chronicled the move to customized application scoring models, with programs such as Automated Underwriting (AU) by Fannie Mae and other decision-making in the mortgage industry. The evolution of the mortgage industry was based on the move to scoring modeling and statistical analysis, from traditional human mortgage underwriting decision-making. By $1995 \mathrm{AU}$ emerged as the predominant method of mortgage underwriting. The move to AU allowed the industry to take advantage of advancement in technology to reduce underwriting cost and increase the efficiency of mortgage underwriting (Straka, 2000). The literature noted the most significant advantage; AU had far superior capability to project the certainty of mortgage repayment by borrowers over traditional human underwriting (Straka, 2000).

AU provided the mortgage industry with the capability to project the likelihood of a borrower paying the 
mortgage over the entire thirty-year period of the mortgage, compared to the likelihood of payment for approximately the first five years for traditional human underwriting (Straka, 2000). By 1995 between 60\% and $70 \%$ of mortgage were underwritten by customized application scoring models taking advantage of the use of advancement in technology. The use of technological advancement was significantly incorporated into the mortgage industry during this period significantly increasing the efficiency and lowering the cost of mortgage servicing, asset valuation, and portfolio analysis. The move to AU significantly streamed lined the mortgage underwriting process, allowing borrowers to receive conditional underwriting approval decisions in minutes, and even same-day closings for some borrowers (Straka, 2000). The literature noted, AU proved to be more accurate, efficient, objective and consistent than traditional human underwriting in the assessment of borrower risk. AU also was an effective tool in the elimination of mortgage discrimination from the mortgage process. AU was especially effective in the underwriting decisions for mortgage approval in cases of marginal and high-risk borrowers (Straka, 2000).

The rapid transformation from print medial real estate listings to online real estate listing significantly changed the real estate industry; exponentially increase the number of potential buyers in the market (Muhanna, 2000). Literature noted, by 2000 advancement in technology had significantly impacted the real estate industry with adaption of the use of the Internet for online real estate listings by most firms in the United States real estate industry. Muhanna (2000) found by 1999 the real estate industry had begun to undergo significant transformation as a result of advancement in information and technology. Survey conducted in the study found a significant increase in the adaption by real estate firm to the use of the internet during the second and third quarter of 1999 by $50 \%$, resulting in about $75 \%$ of all real estate firms taking part in the survey having an internet presence (Muhanna, 2000).

The rapid adaptation of advancement in technology in the real estate industry and the rapid adaptation of technology that streamlined mortgage underwriting process over a very short period of time, were significant factors leading to rapid growth of the mortgage industry and the real estate industry, starting in the late 1990's. The rapid shift to online real estate listings and online mortgage loan applications made significant increased buyers and mortgage lending. The ease of accessibility allowed real estate transaction to be completed very quickly, while lowering cost. The streamline of the mortgage process reduced cost and made mortgage processing far more efficient, significantly shortening the mortgage-processing period to the point that some real estate transaction had same-day mortgage closings. The changes significantly increased real estate sales and mortgage origination production over a very short time. As a result of the increased demand real estate prices significantly increased.

\section{Methodology}

In this section, the researcher discussed the methodology used in the current study. The researcher identified the population and sample for the research. Sampling procedures, data analysis plan, threats to validity, and ethical procedures were also included in the methodology section. The researcher concluded with a summary.

\section{Research Question}

Does the data provide evidence supporting the idea, the failure to consider the impact of rapid adaptation of advancement in technology on the mortgage industry and the real estate industry in the United States preceding the Global Financial Crisis of 2007 and 2008 is the most critical mistake that lead to the false conclusion of a real estate bubble United States housing market which confirms the Eddison Walters Risk Expectation Theory of the Global Financial Crisis of 2007 and 2008?

\section{Hypothesis}

Ho: The evidence suggested, the failure to consider the impact of rapid adaptation of advancement in technology on mortgage lending and the real estate industry in the United States was not the most critical factor that led to the false conclusion of the existence of a real estate bubble in the United States preceding the Global Financial Crisis of 2007 and 2008.

Ha: The evidence suggested, the failure to consider the impact of rapid adaptation of advancement in technology on mortgage lending and the real estate industry in the United States was the most critical factor that led to the false conclusion of the existence of a real estate bubble in the United States preceding the Global Financial Crisis of 2007 and 2008.

\section{Research Design}

The study was a quantitative research design that analyzed variables using linear and none-linear regression analysis, time series analysis, and correlation analysis. Secondary data was collected from the Federal Housing 
Finance Agency database mortgage lending in the United States preceding 2007. Data preceding 2007 was examined to gain an understanding of the impact of rapid adaptation of advancement in technology on the mortgage industry in the United States preceding the Global Financial Crisis of 2007 and 2008. Secondary data from the World Bank Database was also collected.

\section{Population}

Cellular phone subscription per 100 in the United States was collected from the World Bank database. Home sales and mortgage data in the United States was collected from FHFA database.

FHFA based on data from the Department of Housing and Urban Development, the Federal Housing Administration (FHA), the Department of Veterans Affairs (VA), the Rural Housing Service (RHS), and Inside Mortgage Finance Publications. (FHFA.gov, 2020)

\section{Sampling and Sampling Procedures}

A number of variables were analyzed in the study. Cellular phone subscription data per one hundred in the United States collected from the World Bank Database for the period from 1990 to 2006 was analyzed in the study. Mortgage originations of single-family conventional and government-backed mortgages, home purchase price data, units of homes sold for the period from 1990 to 2006 was collected for the study. Mortgage delinquency rates for the last twenty quarters preceding the Global Financial Crisis of 2007 and 2008 from 2002Q1 to 2006Q4, was also collected for the study. The data analyzed allowed the researcher to gain insight into changes in the real estate industry and the mortgage industry in the United States resulting from the rapid adaptation of advancement in technology preceding the Global Financial Crisis of 2007 and 2008. A major goal of the current study was to gain insight into the effectiveness of the implementation of advancement in technology through the modeling programs for underwriting decisions such as AU, in the mortgage underwriting process for the twenty quarters preceding the Global Financial Crisis of 2007 and 2008. Both single-family conventional and government-backed mortgages data, and national mortgage delinquency data were collected from the Federal Housing Finance Agency Database.

\section{Threats to Validity}

The validity of the data for the study was established in the literature. Federal Housing Finance Agency database was established as a reliable source for collection secondary data in the literature. The World Bank Database was established as a reliable source for collecting secondary data in the literature. Because the study focused on the impact of technology on the mortgage industry preceding the Global Financial Crisis of 2007 and 2008, the data analyzed in the study preceded the 2007. To avoid the data being significantly skewed from government intervention policies and the financial turmoil, data analyzed in the current study was collected through the end of 2006 before the start of the financial crisis.

\section{Ethical Procedures}

Secondary data was collected from the Federal Housing Finance Agency Database and the World Bank Database, which are existing database. There were no human subjects involved in the research.

\section{Results and Discussion}

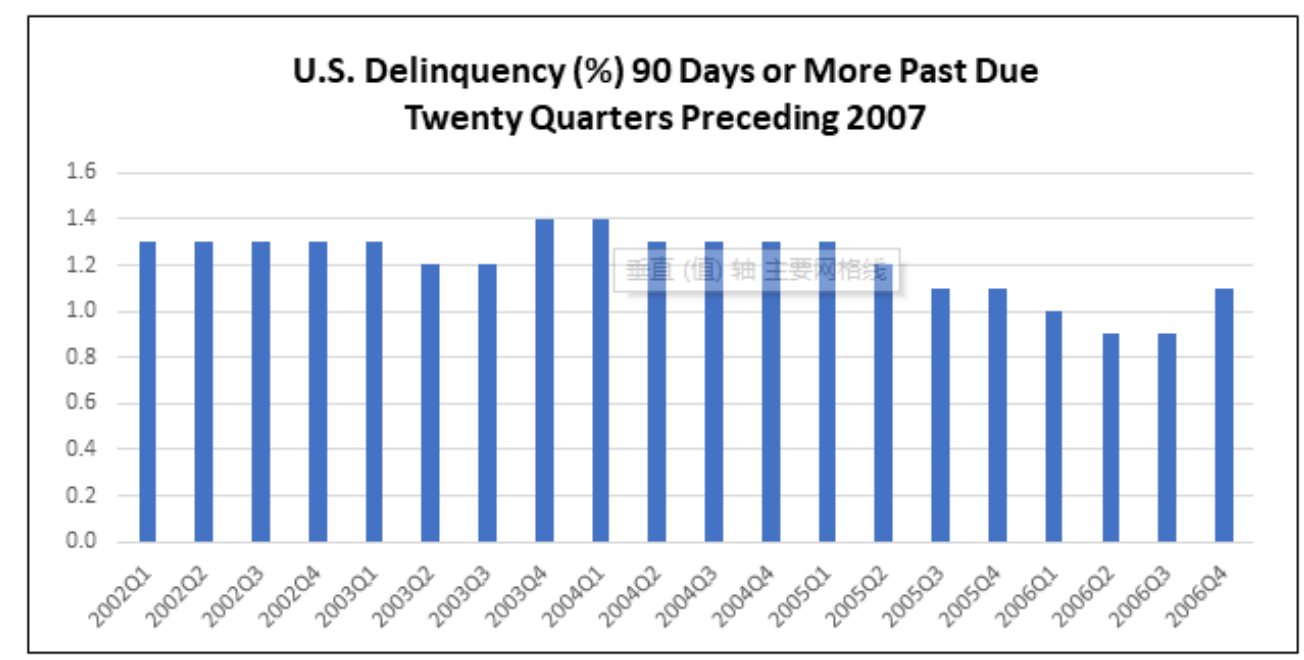

Figure 1. U.S. Mortgage Delinquency Last Twenty Quarters Preceding 2007 from 2002Q1 - 2006Q4 


\section{Data Analysis Results}

The rapid transformation of mortgage underwriting processing from rapid adaptation of advancement in technology created more efficient mortgage underwriting and was a significant factor that increased mortgage lending in the United States. Figure 1 analysis confirmed significant efficiency gains by the adaptation of advancement in technology in mortgage underwriting for the last twenty quarters preceding 2007. Data analysis confirmed record low mortgage delinquency rate for homes ninety days or more past due,

Table 1. Linear Regression Correlation 1990-2006: Dependent Variable Home Purchase Price (\$000): Independent Variable Single-Family Mortgage Originated $(\$ 000,000)$

\begin{tabular}{|c|c|c|c|c|}
\hline Variable & Coefficient & Std. Error & t-Statistic & Prob. \\
\hline SINGLE_FAMILY_MORTGAGES_\$MLL & $\begin{array}{l}119.6577 \\
4.54 \mathrm{E}-05\end{array}$ & $\begin{array}{l}11.30256 \\
5.75 \mathrm{E}-06\end{array}$ & $\begin{array}{l}10.58678 \\
7.885967\end{array}$ & $\begin{array}{l}0.0000 \\
0.0000\end{array}$ \\
\hline $\begin{array}{l}\text { R-squared } \\
\text { Adjusted R-squared } \\
\text { S.E. of regression } \\
\text { Sum squared resid } \\
\text { Log likelihood } \\
\text { F-statistic } \\
\text { Prob(F-statistic) }\end{array}$ & $\begin{array}{r}0.805670 \\
0.792715 \\
25.67543 \\
9888.419 \\
-78.23216 \\
62.18848 \\
0.000001\end{array}$ & \multicolumn{2}{|c|}{$\begin{array}{l}\text { Mean dependent var } \\
\text { S.D. dependent var } \\
\text { Akaike info criterion } \\
\text { Schwarz criterion } \\
\text { Hannan-Quinn criter. } \\
\text { Durbin-Watson stat }\end{array}$} & $\begin{array}{l}194.0412 \\
56.39415 \\
9.439077 \\
9.537102 \\
9.448821 \\
1.004883\end{array}$ \\
\hline
\end{tabular}

in danger of being foreclose for the twenty quarters preceding 2007 at a time when it was alleged by the irresponsible media narrative, a real estate bubble existed caused by borrowers who were approved for risky mortgages they could not afford. The result of data analysis in Figure $\mathbf{1}$ is further confirmation the existence of a real estate bubble did not exist, because one would expect to see significant evidence of homeowner distress in the market instead on record low rates for homeowners ninety days past due and in danger of being foreclosed. The data analysis even showed the last four quarters preceding 2007 was the lowest foreclosure rate of any four consecutive four quarters analyzed. The results of analysis presented in Figure $\mathbf{2}$ confirm the significant growth of mortgage lending between 1990 and 2006. The significant growth in mortgage lending contributed to rapid the growth home purchase price between 1990 through 2006 preceding the Global Financial Crisis of 2007 and 2008 as confirmed by Table 1. The results of regression analysis in Table 1 for correlation of the two variables reviled $80.57 \%$ of the increase in home purchase price from the analysis of the two variables is explained by the increase in mortgage lending during from 1990 through 2006 preceding the Global Financial Crisis of 2007 and 2008. 


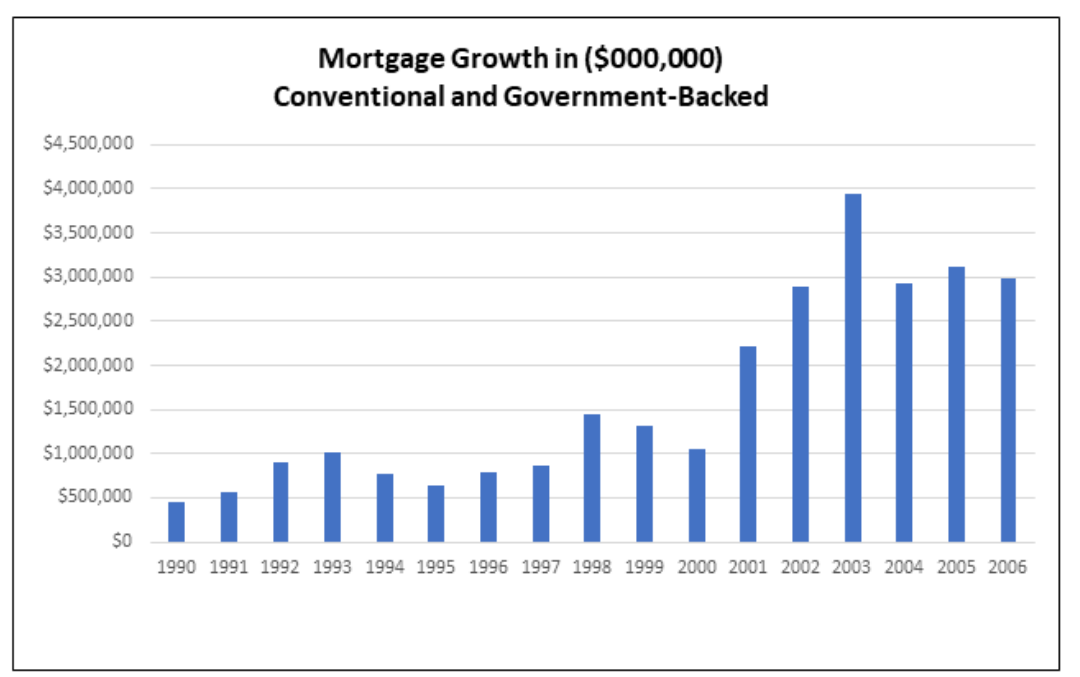

Figure 2. Originations of Single-Family Mortgage 1990 - 2006

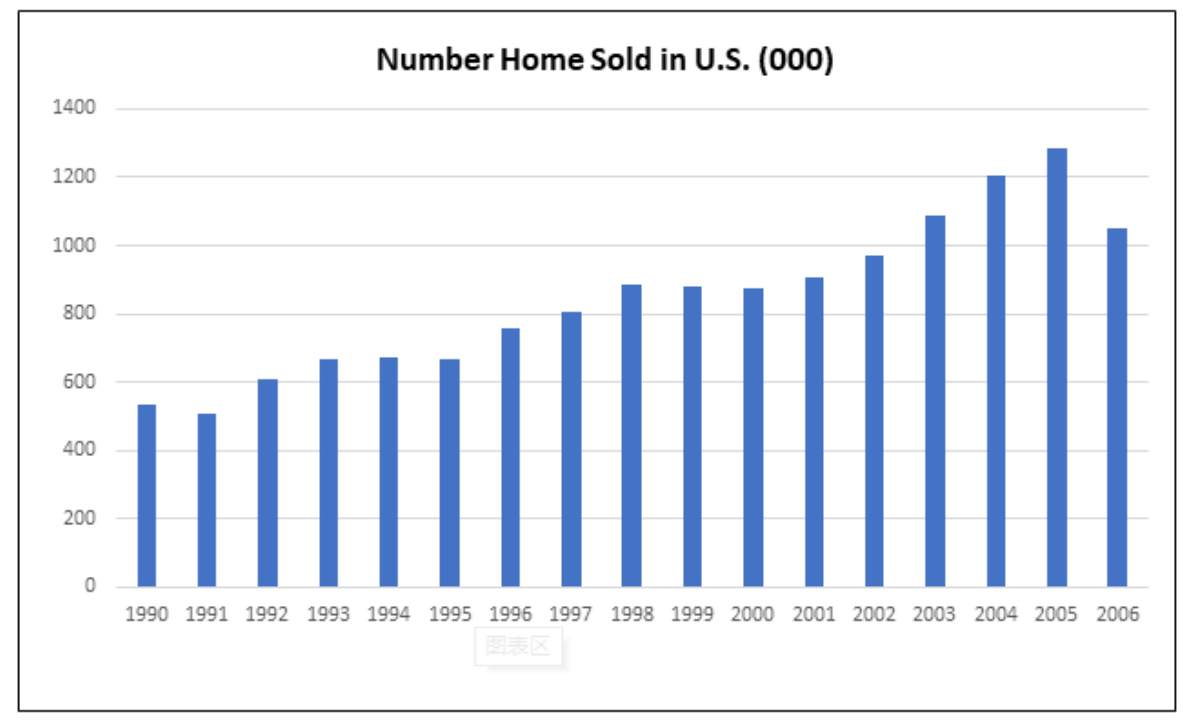

Figure 3. Annual Home Sales U.S. (000) 1990-2006

The fact the rapid adaptation of advancement in technology was not considered as a factor in evaluating the increase in the rapid increase in mortgage lending and the rapid increase in home purchase prices in the United States preceding the Global Financial Crisis of 2007 and 2008 was a significant error. Data analysis in Figure 3 confirmed the rapid growth in real estate sales between 1990 through 2006 preceding the crisis. The results of data analysis in Table 2 confirmed the impact of the rapid adaptation of advancement in technology with linear regression analysis for correlation of the two variables reveled $88.93 \%$ of the increase in units sold was explained by advancement in technology, represented by cellular phone subscriptions in the analysis. Data analysis in Table 3 using nonlinear regression resulted in $84.30 \%$ of the increase in home purchase price explained by the increase in units sold, in the analysis of correlation between the two variables. 
Table 2. Linear Regression Correlation 1990-2006: Dependent Variable Units Sold Homes (\$000): Independent Variable Mobile Cellular Subscription Per 100 (Advancement in Technology)

\begin{tabular}{|c|c|c|c|c|}
\hline Variable & Coefficient & Std. Error & t-Statistic & Prob. \\
\hline MOBILE_CELLULAR_SUBSCRIPTIONS_ & $\begin{array}{l}579.7222 \\
8.538955\end{array}$ & $\begin{array}{l}30.61022 \\
0.777928\end{array}$ & $\begin{array}{l}18.93885 \\
10.97654\end{array}$ & $\begin{array}{l}0.0000 \\
0.0000\end{array}$ \\
\hline $\begin{array}{l}\text { R-squared } \\
\text { Adjusted R-squared } \\
\text { S.E. of regression } \\
\text { Sum squared resid } \\
\text { Log likelihood } \\
\text { F-statistic } \\
\text { Prob(F-statistic) }\end{array}$ & $\begin{array}{r}0.889286 \\
0.881905 \\
77.48436 \\
90057.40 \\
-97.00936 \\
120.4844 \\
0.000000\end{array}$ & \multicolumn{2}{|c|}{$\begin{array}{l}\text { Mean dependent var } \\
\text { S.D. dependent var } \\
\text { Akaike info criterion } \\
\text { Schwarz criterion } \\
\text { Hannan-Quinn criter. } \\
\text { Durbin-Watson stat }\end{array}$} & $\begin{array}{l}844.9412 \\
225.4752 \\
11.64816 \\
11.74619 \\
11.65790 \\
1.385481\end{array}$ \\
\hline
\end{tabular}

Table 3. Nonlinear Regression Correlation 1990-2006: Dependent Variable Home Purchase Price (\$000): Independent Variable Units Sold Homes (\$000)

\begin{tabular}{|c|c|c|c|c|}
\hline Variable & Coefficient & Std. Error & t-Statistic & Prob. \\
\hline UNITS_SOLD_IN_THOUSAND & $\begin{array}{l}94.91443 \\
0.000130\end{array}$ & $\begin{array}{l}11.93318 \\
1.40 \mathrm{E}-05\end{array}$ & $\begin{array}{l}7.953828 \\
9.323611\end{array}$ & $\begin{array}{l}0.0000 \\
0.0000\end{array}$ \\
\hline $\begin{array}{l}\text { R-squared } \\
\text { Adjusted R-squared } \\
\text { S.E. of regression } \\
\text { Sum squared resid } \\
\text { Log likelihood } \\
\text { F-statistic } \\
\text { Prob(F-statistic) }\end{array}$ & $\begin{array}{r}0.852840 \\
0.843029 \\
22.34311 \\
7488.218 \\
-75.86887 \\
86.92972 \\
0.000000\end{array}$ & \multicolumn{2}{|c|}{$\begin{array}{l}\text { Mean dependent var } \\
\text { S.D. dependent var } \\
\text { Akaike info criterion } \\
\text { Schwarz criterion } \\
\text { Hannan-Quinn criter. } \\
\text { Durbin-Watson stat }\end{array}$} & $\begin{array}{l}194.0412 \\
56.39415 \\
9.161044 \\
9.259069 \\
9.170788 \\
1.041749\end{array}$ \\
\hline
\end{tabular}

\section{Hypotheses Testing}

Ho: The evidence suggested, the failure to consider the impact of rapid adaptation of advancement in technology on mortgage lending and the real estate industry in the United States was not the most critical factor that led to the false conclusion of the existence of a real estate bubble in the United States preceding the Global Financial Crisis of 2007 and 2008. Based on the evidence from data analysis, the researcher rejected Ho.

Ha: The evidence suggested, the failure to consider the impact of rapid adaptation of advancement in technology on mortgage lending and the real estate industry in the United States was the most critical factor that led to the false conclusion of the existence of a real estate bubble in the United States preceding the Global Financial Crisis of 2007 and 2008. Based on the evidence from data analysis the researcher failed to reject Ha.

The evidence from data analysis in the current study suggested, the most critical error leading to the false conclusion of a real estate bubble preceding the Global Financial Crisis of 2008 and 2008, was the failure to consider the rapid adaptation of advancement of technology in the mortgage industry and the real estate industry in the United States.

\section{Discussion}

The cause of the Global Financial Crisis of 2007 and 2008 is a topic that have been widely researched, but the lack of evidence supporting the existence of a real estate bubble have been a significant issue throughout the bobby of literature. Significant questions were raised regarding the lack of evidence supporting the existence of a real estate bubble preceding the Global Financial Crisis of 2007 and 2008 in Walters (2018) and Walters and Djokic (2019). Data analysis in recent studies by the current researcher presented evidence suggesting the existence of a real estate bubble preceding the Global Financial Crisis of 2007 and 2008 was a false conclusion. Data analysis from Walters (2019) resulted in 194.041 Mean Dependent Variable, 0.989 Adjusted R-square, 5.908 Square Error of Regression, and 488.726 Sum-of-Square Residual from nonlinear regression analysis with 
the independent variable of "advancement in technology", which proved to be the most significant factor causing the dependent variable of "home purchase price" to increase preceding the Global Financial Crisis of 2007 and 2008. Based on the findings of data analysis in Walters (2019), the researcher concluded the data confirmed the assertion agreed upon by Alan Greenspan and Ben Bernanke, it was impossible to have a real estate bubble while citing the Efficient Market Hypothesis in 2005. Subsequent to 2005 alternative attempts to explain the existence of a real estate bubble were made by both former Chairmen of the Federal Reserve Board. Subprime lending and low interest rates were ruled out as the cause of the Global Financial Crisis of 2007 and 2008 in Walters (2019). As a result of the findings from Walters (2019), further investigation to gain an understanding of the impact of the rapid adaption of advancement in technology influence on the rapid increase in home purchase price preceding the Global Financial Crisis of 2007 and 2008 was required. The current study analyzed additional variable that confirmed advancement in technology was the most significant causing home prices to increase preceding the Global Financial Crisis of 2007 and 2008.

By the time the turmoil in the real estate market begun in 2007, both the mortgage industry and the real estate industry in the United States was completely transformed as a result rapid adaptation of advancement in technology from the mortgage and the real estate industry that existed just one decade before. The rapid adaptation of advancement in technology in the mortgage industry resulted in greater mortgage underwriting efficiency, faster mortgage underwriting decisions, and lower cost. Data analysis in the current study reveled record low mortgage delinquency rates for mortgages at least ninety days past due in danger of foreclosure for the last four quarters preceding 2007. The existence of low mortgage delinquency rates is additional confirmation the existence of a real estate bubble was a false conclusion. The rapid transformation of real estate listings from print media to online listings over a very short time period as a result of advancement in technology drastically increased the marketability of real estate, resulting in a substantial increase in potential buyers. Potential buyer could view home through virtual tours. Rapid adaptation of advancement in technology resulted in virtual tours of homes and entire neighborhoods being available online. With the capability of street-view on websites such as Google Maps, buyers could tour the entire neighborhoods around a property listed for sale using the Internet in additional to touring the homes. The ability to view many more homes in a short period of time significantly shortened the home buying process. The move to online listing meant buyer from anywhere in the world could view real estate listing and place bid on real estate without being in close proximate to the property.

The false conclusion of a real estate bubble was the most significant factor leading to the Global Financial Crisis of 2007 and 2008. The dissemination of the false information of a real estate bubble by irresponsible media coverage was the most significant factor causing the false conclusion of the real estate bubble. Irresponsible media was not solely responsible, but most likely the interest by the media resulted from their narrative that supported 2008 United States Presidential Election bias. It appears the media was far more interested in their own narrative, than asking questions that would have required individuals making false claims of a real estate bubble to produce evidence. The result of the media failure was, risk expectation to increase so significantly, investors in mortgage-backed securities withdraw their capital from mortgage backed securities resulting in a significant decrease in mortgage lending. The false conclusion of a real estate bubble was the most significant factor leading to Global Financial Crisis of 2007 and 2008 which many in the literature refer too as, the greatest economic event since the Great Depression.

The response by the United States Federal Government to the 2008 real estate crash under the Obama Administration drastically worsened conditions in the real estate market in the United States, resulting in a total collapse of the United States economy and a worldwide economic collapse. President George W. Bush Administration signed the Trouble Asset Relief Program (TARP) into law in October 2008. The inception of the program was aimed at purchasing what was labeled at the time as "toxic mortgage assets". It is now know, real estate assets were priced efficiently based on the Efficient Market Hypothesis. If TARP had been implemented as the program was conceived, the funding would have injected capital back into the real estate market increasing the capital available for lending significantly, resulting in a much softer landing in the real estate market. The second critical mistake, which had a catastrophic effect on the United States economy, was the enactment of Dodd-Frank, which was signed into law one and a half years later. Dodd-Frank restricted mortgage lending at a time when the most significant factor causing the crisis was, the lack of mortgage lending. Results from data analysis in Walters (2018) of 34 developed countries and 36 developing countries reveled, the lasting effects from the Global Financial Crisis of 2007 for economic growth and trade exports for developing economies such as China, was significant economic hardship. For developing economies such as China relying heavily on exports, the economic hardship was even for significant. The analysis of data in Walters (2018) resulted in 
evidence suggesting there was almost no growth in exports for developing countries around the world.

\section{Conclusion}

The rapid adaption of advancement in technology significantly changed the mortgage industry and the real estate industry and significantly increasing the marketability of real estate and potential buyer. As a result real estate sale increased rapidly, resulting in a rapid increase in home purchase price preceding the Global Financial Crisis of 2007 and 2008. The Global Financial Crisis of 2007 and 2008 resulted from false information spread through irresponsible media reporting. The false conclusion of a real estate was widely accepted because, understanding the true nature of the turmoil in the real estate market required an approach with no assumptions. Once the assumption of a real estate bubble was accepted, analysis focused on explaining the existence of the real estate bubble and not on understanding the true mature of the crisis. The Global Financial Crisis of 2007 and 2008 was a tragedy that could have been completely avoided. The tragedy affected economies around the entire world. Much of the world's economy continues to suffer the lasting effects of the Global Financial Crisis of 2007 and 2008 today. Media broadcasters completely failed the entire world, because the reports never ask the tough questions forcing economist to produce evidence in support of the false claim of a real estate bubble that never existed. It is quite troubling, such a significant error could continue for as long as it did. It is critical to gain an understanding of how such a tragedy could have taken place at a time when an abundance of information is available at the fingertips. Lessons learn from the mistakes made which caused the Global Financial Crisis of 2007 and 2008 can prevent another crisis in the future.

The researcher calls for additional studies focused on understanding factor that contributed to the financial crisis. Future investigation aimed at gaining an understanding of true nature of the Global Financial Crisis of 2007 and 2008 is needed in order to reconsider the literature, based on new information uncovered in recent studies.

\section{Reference}

Belke, A., \& Wiedmann, M. (2005). Boom or bubble in the US real estate market? Inter economics, 40(5), 273-284. https://doi.org/10.1007/s10272-005-0157-0

Muhanna, W. A. (2000). E-Commerce in the real estate brokerage industry. Journal of Real Estate Practice and Education, 3(1), 1-16. https://doi.org/10.1080/10835547.2000.12091570

FHFA.gov. (2020). Federal Housing Finance Agency. Retrieved from http://www.fhfa.gov/PolicyProgramsResearch/Research/PaperDocuments/200507_RP_SFMortgagesOrigin atedOutstanding_1990-2004_N508.pdf

Greenspan, A., Mankiw, N. G., \& Stein, J. C. (2010). The crisis/comments and discussion. BrookingsPapers on Economic Activity, 201-261. Retrieved from https://searchproquest-com.prxkeiser.lirn.net/docview/749024349?accountid=35796

Glynn, C. J., Huge, M. E., \& Hoffman, L. H. (2008). Did the media help inflate thehousing bubble? Media coverage of real estate markets in times of change. Presented at the Association for Education in Journalism $\&$ Mass Communication Annual Conference.

Khayoyan, A. (2012). The U.S. housing crisis: Analyzing the differing arguments of John Taylor and AlanGreenspan (Order No. 3522042). Available from ProQuest Dissertations \&Theses Global;ProQuest Dissertations \& Theses Global: The Humanities and Social Sciences Collection.(1036992081). Retrieved from https://search-proquest-com.prx keiser.lirn.net/docview/1036992081?accountid=35796

Roach, S. S. (2005). Alan Greenspan. Foreign Policy, 18-24. Retrieved from https://search.proquest.com/docview/224046398? accountid=35796

Starr, M. A. (2012). Contributions of economists to the housing-price bubble. Journal of Economic Issues, 46(1), 143-171. Retrieved fromhttps://search.proquest.com/docview/963335200? accountid=35796

Straka, J. W. (2000). A shift in the mortgage landscape: The 1990's move to automated credit evaluations. Journal of Housing Research, 11(2), 207-231. Retrieved from https://pdfs.semanticscholar.or/38ce/5ff03c453f2594251dec35203b3891dcedaf.pdf

Walters, E. T. (2018). Changes in FDI inflows and economic growth and the effect on exports: The aftermath of the global financial crisis of 2007 and 2008 (Order No.10976977). Available from ProQuest OneAcademic. (2135243535). Retrieved from https://search.proquest.com/docview/2135243535?accountd=35796

Walters, E. T. (2019). Growth in home purchase price preceding crisis explained by technology advancement: Eddison Walters risk expectation theory of the global financial crisis of 2007 and 2008 confirmed. Journal 
of International Business and Economics, 7(2), 140-153. Published by American Research Institute for Policy Development. https://doi.org/10.15640/jibe.v7n2a15

Walters, E., \& Djokic, B. (2019). No real estate bubble preceding global financial crisis: Eddison Walters risk expectation theory of the global financial crisis of 2007 and 2008, Journal of International Business and Economics, 7(2), 1-11. Published by American Research Institute for Policy Development. https://doi.org/10.15640/jibe.v7n2a1

World Bank.org. (2020). World Bank Database. Retrieved from https://data.worldbank.org/indicator/IT.CEL.SETS.P2

\section{Copyrights}

Copyright for this article is retained by the author(s), with first publication rights granted to the journal.

This is an open-access article distributed under the terms and conditions of the Creative Commons Attribution license (http://creativecommons.org/licenses/by/4.0/). 